\title{
Antiinflammatory effect of androgen receptor activation in human benign prostatic hyperplasia cells
}

\author{
Linda Vignozzi ${ }^{1,2, *}$, Ilaria Cellai ${ }^{1,2, *}$, Raffaella Santi ${ }^{4}$, Letizia Lombardelli ${ }^{5}$, Annamaria Morelli ${ }^{1,2}$, \\ Paolo Comeglio ${ }^{1,2}$, Sandra Filippi ${ }^{3}$, Federica Logiodice ${ }^{5}$, Marco Carini ${ }^{6}$, Gabriella Nesi ${ }^{4}$, Mauro Gacci ${ }^{6}$, \\ Marie-Pierre Piccinni ${ }^{5}$, Luciano Adorini ${ }^{7}$ and Mario Maggi ${ }^{1,2}$ \\ ${ }^{1}$ Sexual Medicine and Andrology Unit, Department of Clinical Physiopathology, University of Florence, Viale Pieraccini 6, Florence 50139, Italy \\ ${ }^{2}$ CIRMAR (Centro Interuniversitario di Ricerca sulle Basi Molecolari della Malattie della Riproduzione), Milan, Italy \\ ${ }^{3}$ Interdepartmental Laboratory of Functional and Cellular Pharmacology of Reproduction, Departments of Pharmacology and Clinical Physiopathology, \\ ${ }^{4}$ Department of Human Pathology and Oncology, ${ }^{5}$ Immunoallergology Unit, Department of Internal Medicine, Center of Excellence for Research, \\ Transfer and High Education DENOTHE and ${ }^{6}$ Department of Urology, University of Florence, Florence, Italy \\ ${ }^{7}$ Intercept Pharmaceuticals, 18 Desbrosses Street, New York, New York 10013, USA \\ (Correspondence should be addressed to M Maggi at Sexual Medicine and Andrology Unit, Department of Clinical Physiopathology, University of Florence; \\ Email: m.maggi@dfc.unifi.it) \\ *(L Vignozzi and I Cellai contributed equally to this work)
}

\begin{abstract}
Progression of benign prostatic hyperplasia (BPH) involves chronic inflammation and immune dysregulation. Preclinical studies have demonstrated that prostate inflammation and tissue remodeling are exacerbated by hypogonadism and prevented by testosterone supplementation. We now investigated whether, in humans, hypogonadism was associated with more severe $\mathrm{BPH}$ inflammation and the in vitro effect of the selective androgen receptor agonist dihydrotestosterone (DHT) on cultures of stromal cells derived from $\mathrm{BPH}$ patients $(\mathrm{hBPH})$. Histological analysis of inflammatory infiltrates in prostatectomy specimens from a cohort of $\mathrm{BPH}$ patients and correlation with serum testosterone level was performed. Even after adjusting for confounding factors, hypogonadism was associated with a fivefold increased risk of intraprostatic inflammation, which was also more severe than that observed in eugonadal $\mathrm{BPH}$ patients. Triggering $\mathrm{hBPH}$ cells by inflammatory stimuli (tumor necrosis factor $\alpha$, lipopolysaccharide, or $\mathrm{CD}^{+}{ }^{+} \mathrm{T}$ cells) induced abundant
\end{abstract}

secretion of inflammatory/growth factors (interleukin 6 (IL6), IL8, and basic fibroblast growth factor (bFGF)). Co-culture of $\mathrm{CD}^{+} \mathrm{T}$ cells with hBPH cells induced secretion of Th1 inducer (IL12), Th1-recruiting chemokine (interferon $\gamma$ inducible protein 10, IP10), and Th2 (IL9)- and Th17 (IL17)-specific cytokines. Pretreatment with DHT inhibited NF- $\kappa \mathrm{B}$ activation and suppressed secretion of several inflammatory/growth factors, with the most pronounced effects on IL8, IL6, and bFGF. Reduced inflammatory cytokine production by testosterone cells, an increase in IL10, and a significant reduction of testosterone cells proliferation suggested that DHT exerted a broad antiinflammatory effect on testosterone cells. In conclusion, our data demonstrate that DHT exerts an immune regulatory role on human prostatic stromal cells, inhibiting their potential to actively induce and/or sustain autoimmune and inflammatory responses.

Journal of Endocrinology (2012) 214, 31-43

\section{Introduction}

Benign prostatic hyperplasia (BPH) is a highly prevalent disorder, ranking among the ten most common diseases in aging men (Issa \& Regan 2007). BPH is commonly viewed as a benign, progressive, growth of the prostate gland, which clinically translates into a spectrum of lower urinary tract symptoms (LUTSs), such as urgency, frequency, weak stream, nicturia, and incomplete bladder emptying.

Although primarily characterized by hyperproliferation of both stromal and epithelial cells, a wealth of recent epidemiological and histopatological studies have clearly evidenced that chronic inflammation is a common finding in BPH (see Kramer et al. (2007), Fibbi et al. (2010b) and Schauer \& Rowley (2011) for reviews). Data from two large-scale studies have indicated that chronic inflammatory infiltrates are associated with higher prostatic volume, a higher risk of $\mathrm{BPH}$ progression, and acute urinary retention (Roehrborn et al. 2007, Nickel et al. 2007, 2008). From a pathophysiological standpoint, these data suggest that chronic inflammation could have a causative effect on BPH/LUTS, rather than merely occurring in response to tissue remodeling. Accordingly, infiltration of chronically activated $\mathrm{CD} 4^{+}$ $\mathrm{T}$ lymphocytes and secretion of inflammatory cytokines 
within the prostatic gland are considered a determinant factor in BPH pathogenesis (see Kramer et al. (2007), Fibbi et al. (2010b) and Schauer \& Rowley (2011) for reviews).

Cytokines, chemokines, and growth factors are involved at each stage of $\mathrm{BPH}$ development and progression. In the initial phase, Th1 lymphocyte accumulation, producing interferon- $\gamma$ (IFN- $\gamma$ ), and interleukin 2 (IL2), prevails and stimulates IL15 production by stromal cells, thus perpetuating the infiltration process. As in other chronic inflammatory immune disorders, a progressive switch from a Th1 response to a less polarized immune response is observed during the disease course (Rotondi et al. 2007). This shift is currently viewed as a counter-regulatory mechanism against inflammation, occurring when the Th1 response becomes dangerous for the host. Indeed, as testosterone lymphocytes progressively accumulate, IL4 and IL13 expression increases, suggesting a shift toward a Th0/Th2 immune response (Steiner et al. 2003a). There is also evidence that a loss of tolerance to self-antigens, associated with expansion of Th17 cells and IL17 overexpression, is crucial in BPH development (Steiner et al. 2003b). This is also supported by the observation that IL8 and IL6, key executors of stromal growth in BPH, are produced by prostatic stromal cells in response to IL17 (Penna et al. 2009), thus linking a self-perpetuating autoimmune response to altered tissue remodeling and hyperplastic growth (Ropiquet et al. 1999).

The causes for inflammation and immune dysregulation in the prostate remain subjects of debate. Potential causes include infectious agents, exposure to other environmental and dietary factors, hormonal and metabolic derangements, or a combination thereof. Animal models have provided a great deal of information about an association between metabolic diseases and LUT alterations (Azadzoi et al. 1999, Kozlowski et al. 2001, Krajewska et al. 2008, Morelli et al. 2012, Vignozzi et al. 2012). Our laboratory has developed, over the last few years, an animal model of metabolic syndrome-associated hypogonadotropic hypogonadism by feeding adult male rabbits a high fat diet (HFD) for 12 weeks (Filippi et al. 2009, Vignozzi et al. 2011, 2012, Morelli et al. 2012). Interestingly, HFD-induced hypogonadism is associated with marked histological alterations of the prostate gland, characterized by inflammation coupled with stromal derangement and hypoxia, which are completely normalized by testosterone supplementation (Vignozzi et al. 2012). However, testosterone supplementation, in parallel with its beneficial effects on the prostate, ameliorates also several metabolic features in HFD-treated rabbits. Hence, a direct protective effect of testosterone on the prostate has not yet been conclusively demonstrated.

In the present work, we examined the antiinflammatory effect of the selective androgen receptor (AR) agonist dihydrotestosterone (DHT) on human prostate by performing a series of in vitro experiments using stromal cells isolated from $\mathrm{BPH}$ patients $(\mathrm{hBPH})$. BPH cells have been previously described to act as antigen-presenting cells (APCs; Penna et al. 2009), thus indicating their potential role in inducing and sustaining an autoimmune response within the prostatic gland. Histological analysis of inflammatory cell infiltrates in prostatectomy specimens from a cohort of BPH patients and their correlation with preoperatory serum testosterone levels were also performed.

\section{Materials and Methods}

\section{Collection of human prostate specimens}

All patients underwent a routine prostatic evaluation, including digital rectal examination, prostatic transrectal ultrasound (TRUS), and measurement of serum total prostate-specific antigen (PSA) level, to exclude the presence of prostatic carcinoma. TRUS was also used to measure the adenoma volume, using the ellipsoidal formula. Suprapubic transvesical prostatectomy was performed under general or spinal anesthesia using a modified Freyer technique, comprising anterior bladder access, enucleation of the adenoma through a circular bladder neck incision, urethral section, and suturing of the prostatic groove.

Transurethral resection of prostate (TURP) was performed with resectoscopes and cutting loops, removing the hyperplastic prostatic tissue of the transition zone. The cutting of prostatic tissue and coagulation of blood vessels are achieved by using adaptable electrical current. Surgical specimens were collected by a sterile procedure and used for both histological examination and laboratory workup after informed consent.

Hypogonadism was defined according to different total testosterone thresholds $(\leq 8, \leq 10 \cdot 4$, and $\leq 12 \mathrm{nmol} / \mathrm{l})$. When the different thresholds were applied 9.5, 21.4, and $38 \cdot 1 \%$ of the population samples respectively satisfied the criteria. Severe hypogonadism was defined as total testosterone $\leq 8 \mathrm{nmol} / 1(230 \mathrm{ng} / \mathrm{dl})$.

\section{Pathological assessment of prostatic inflammatory infiltrates}

A series of 42 patients undergoing open prostatectomy for $\mathrm{BPH}$ were analyzed by two independent pathologists ( $G \mathrm{~N}$ and $\mathrm{R} \mathrm{S}$ ), blinded to clinical findings. All surgical specimens were investigated for the presence of an inflammatory infiltrate, according to the standardized classification system of chronic prostatitis/chronic pelvic pain syndrome of the National Institutes of Health (NIH; Nickel et al. 2001). The following parameters were assessed: prevalent anatomical location (stromal, periglandular, and glandular), grade (mild, moderate, and severe), and extent (focal (10\%), multifocal $(10-50 \%)$, and diffuse $(>50 \%))$ of inflammatory infiltrates and presence/absence of glandular disruption. For the purposes of statistical analysis, an 'inflammatory score' (IS) combining all the above-mentioned histological parameters was defined. Five micron-thick sections were cut from formalin-fixed paraffin-embedded prostatic tissues for immunohistochemical analysis. A mouse monoclonal ready-to-use anti-CD45 
antibody (Ab; clone 2B11 and PD7/26; Ventana Medical Systems, Inc., Tucson, AZ, USA) was employed as Ab.

All tissue sections were placed on the Ventana automated stainer BenchMark XT ICH system where they were deparaffinized, rehydrated, and processed for blocking the endogenous peroxidase and epitope retrieval. Following the Ventana staining procedure, the primary $\mathrm{Ab}$ was then placed on the tissue sections and incubated for $32 \mathrm{~min}$ at $37^{\circ} \mathrm{C}$, using the iVIEW DAB detection kit as the revelation system. After the staining run had been completed, the tissue sections were removed from the stainer, counterstained with Mayer's hematoxylin, dehydrated, and mounted in permanent mounting medium. The negative control was performed by substituting the primary $\mathrm{Ab}$ with a Ventana dispenser filled with nonimmune serum at the same concentration as the primary Ab. Known positive controls were used throughout. The control sections were treated in parallel with the samples and in the same run.

\section{Human prostatic stromal cell cultures}

Primary human prostatic smooth muscle cells $(\mathrm{hBPH})$ were obtained and cultured as previously described (Crescioli et al. 2000, Fibbi et al. 2010a,b). Briefly, six different hBPH cell preparations were obtained from prostate tissues derived from six patients who underwent TURP or suprapubic adenomectomy for BPH after informed consent. Patients did not receive any pharmacological treatment in the 3 months preceding surgery. Surgical specimens were cut into small fragments and treated overnight with $2 \mathrm{mg} / \mathrm{ml}$ bacterial collagenase type IV (Sigma-Aldrich). Fragments were then extensively washed in PBS and cultured in a DMEM-F12 1:1 mixture supplemented with $10 \%$ heat-inactivated FBS, $2 \mathrm{mM}$ glutamine, $100 \mathrm{U} / \mathrm{ml}$ penicillin, and $100 \mu \mathrm{g} / \mathrm{ml}$ streptomycin in a fully humidified atmosphere of $95 \%$ air and $5 \% \mathrm{CO}_{2}$. Cells began to emerge within 1 week and were used within the tenth passage.

\section{Cytokine and chemokine production by BPH cells}

Basal secretion of cytokines and chemokines in not-irradiated $\mathrm{BPH}$ and the antiinflammatory effects of DHTwere tested in a different set of experiments as follows: $\mathrm{BPH}$ cells were stimulated with tumor necrosis factor $\alpha(\mathrm{TNF} \alpha ; 10 \mathrm{ng} / \mathrm{ml}$ for $5 \mathrm{~h}$ ) or lipopolysaccharide (LPS; $100 \mathrm{ng} / \mathrm{ml}$ for $48 \mathrm{~h}$ ) in the presence or absence of DHT $(30 \mathrm{nM})$ added $24 \mathrm{~h}$ before cell stimulation. Cell culture supernatants were analyzed with the bead-based multiplex assay (Bio-Rad). Experiments were performed in triplicate using four different $\mathrm{BPH}$ cell preparations.

\section{Generation of $\mathrm{CD}^{+} \mathrm{T}$ cell clones from peripheral blood of healthy subjects}

To generate T-cell clones, peripheral blood mononuclear cells (PBMCs) from normal subjects were seeded under limiting dilution conditions $(0 \cdot 3$ cells/well $)$ in round-bottomed microwell plates containing $10^{5}$ irradiated (9000 rads) allogeneic PBMCs (as feeder cells) and Phytohemagglutinin (PHA) (1\% vol/vol; Gibco Laboratories) in a final volume of $0 \cdot 2 \mathrm{ml}$ of RPMI-1640 supplemented with $2 \mathrm{mM}$ L-glutamine, $2 \times 10^{-5}$ M 2-mercaptoethanol, IL2 $(50 \mathrm{U} / \mathrm{ml}$; Eurocetus, Milano, Italy), and 10\% FCS (HyClone Laboratories, Inc., Logan, UT, USA), as we reported elsewhere (Piccinni et al. 1995). Growing microcultures were then supplemented, at weekly intervals, with IL2 $(50 \mathrm{U} / \mathrm{ml})$ and irradiated feeder cells. The phenotype distribution of T-cell clones was assessed by flow cytometric analysis, using anti-CD4 and anti-CD8 MABs (Becton Dickinson, Mountain View, CA, USA). For co-cultures with $\mathrm{hBPH}$ cells, $\mathrm{CD}^{+}{ }^{+} \mathrm{CD} 4^{+} \mathrm{T}$ cell clones showing a Th0 profile were selected, thus producing IL4, IL5, IL13, and IFN- $\gamma$ as measured by multiplex bead-based assay (Bio-Rad).

\section{Determination of cytokine and chemokine concentrations}

The quantitative determination of cytokines was performed with a bead-based multiplex immunoassay, as previously described (Lédée et al. 2008). Briefly a bead-based multiplex immunoassay (Bio-Rad) and a Bioplex 200 system (Bio-Rad; Luminex Map Technology) were used to measure simultaneously in cell culture supernatants the concentrations of the following cytokines and chemokines: IL1 $\beta$, IL1Ra, IL2, IL4, IL5, IL6, IL8, IL9, IL10, IL12, IL13, IL15, IL17A, IFN- $\gamma$, TNF $\alpha$, G-CSF, GM-CSF, VEGF, PDGF, basic fibroblast growth factor (bFGF) interferon $\gamma /$ inducible protein-10 (IP-10), monocyte chemotactic protein-1 (MCP-1), RANTES, eotaxin, macrophage inflammatory protein- $1 \alpha$ (MIP-1 $\alpha$ ), and MIP-1 $\beta$. In brief, $50 \mu 1$ of each supernatant were added to $50 \mu \mathrm{l}$ of $\mathrm{Ab}$-conjugated beads directed against the analytes listed above (Bio-Rad) in a 96-well filter plate (Bio-Rad). After a 30-min incubation, the plate was washed and $25 \mu \mathrm{l}$ of biotinylated anticytokine Ab solution was added to each well before another 30-min incubation. The plate was then washed and $50 \mu \mathrm{l}$ of streptavidin-conjugated phycoerythrin $(\mathrm{PE})$ were added to each well. After a final wash, each well was resuspended with $125 \mu \mathrm{l}$ of assay buffer (Bio-Rad) and analyzed with the Bioplex 200 system (Bio-Rad). Standard curves were derived from various concentrations of the different cytokine standards in the assay and followed the same protocol as the supernatant samples. The concentration of each cytokine $(\mathrm{pg} / \mathrm{ml})$ in each supernatant was calculated thanks to the software of the Bioplex. The assay sensitivity for all proteins tested was $<1 \mathrm{pg} / \mathrm{ml}$.

\section{Proliferation of T-cell clones stimulated by immobilized anti-CD3 Abs in the presence of irradiated $h B P H$ cells}

$\mathrm{BPH}$ cells pretreated or not with $30 \mathrm{nM}$ DHT for $24 \mathrm{~h}$ were then irradiated $(9000 \mathrm{rads})$ and co-cultured with $\mathrm{CD}^{+}$ $\mathrm{CD}^{+}{ }^{+}$Th0-type T-cell clones for $48 \mathrm{~h}$. In brief, $10^{5} \mathrm{~T}$-cell blasts obtained from T-cell clones in $0 \cdot 2 \mathrm{ml}$ RPMI-1640 
medium supplemented with $2 \mathrm{mM}$ L-glutamine, $2 \times 10^{-5} \mathrm{M}$ 2-mercaptoethanol and 10\% FCS (Hyclone Laboratories, Inc.) were stimulated in 96 U-bottomed plates with immobilized anti-CD3 antibodies (Ortho Pharmaceuticals, Raritan, NJ, USA) in the absence or presence of $3 \times 10^{4}$ irradiated (9000 rads) hBPH cells for $48 \mathrm{~h}$. After a 16-h pulse with $0.5 \mu \mathrm{Ci}{ }^{3} \mathrm{H}-\mathrm{TdR}$ (Amersham International), cultures were harvested and radioactivity measured by liquid scintillation.

\section{Induction of cytokine and chemokine production by $\mathrm{CD} 4^{+}$ ThO-type T-cell clones in response to irradiated $h B P H$}

Irradiated (9000 rads) BPH cells, pretreated or not with $30 \mathrm{nM}$ DHT for $24 \mathrm{~h}$, were co-cultured in $0 \cdot 2 \mathrm{ml}$ of complete medium in 96 U-bottomed plates with $\mathrm{CD}^{+}{ }^{+} \mathrm{CD}^{+}$Th0-type T-cell clones for $48 \mathrm{~h}$, as described above. After $48 \mathrm{~h}$, supernatants were collected and stored in aliquots at $-80^{\circ} \mathrm{C}$ until used. The experiments were performed in triplicate using six different BPH cell preparations. Each T-cell clone was separately co-cultured with each $\mathrm{BPH}$ cell preparation.

The modulation of each T-cell clone was verified by cultures of immobilized anti-CD3 $\mathrm{CD} 4{ }^{+} \mathrm{T}$ cell clones cultured in the presence of IL12 $(5 \mathrm{ng} / \mathrm{ml})$, which is a wellknown inducer of IFN- $\gamma$ production. If the T-cell clones did not show an increased production of IFN- $\gamma$, the T-cell clones were not modulated and therefore were excluded from the statistical analysis of our results. A total of 15 IL12-responsive T-cell clones were analyzed statistically.

\section{$R N A$ extraction and quantitative RT-PCR analysis}

Total RNA was extracted from $\mathrm{hBPH}$ samples using RNAeasy kit (Qiagen), according to the manufacturer's instructions, and cDNA synthesis was carried out using the RT kit purchased from Applied Biosystems. Quantitative RT-PCR (qRT-PCR) was performed by TaqMan Real-Time PCR Master Mix (Applied Biosystems) with the following thermal cycler conditions: 40 cycles at $95^{\circ} \mathrm{C}$ for $15 \mathrm{~s}$ and $60{ }^{\circ} \mathrm{C}$ for $1 \mathrm{~min}$. Primers and probe for human cyclooxygenase-2 (COX2 or PTGS2 according to the HUGO Database) was purchased from Applied Biosystems (assay ID: Hs00153133_m1). Amplification and detection were performed with MyiQTM 2 Two-Color Real-Time PCR Detection System (Bio-Rad). The expression of $18 \mathrm{~S}$ rRNA subunit, chosen as reference gene, was quantified with a predeveloped assay (Applied Biosystems) and used for normalization and relative quantitation of the target gene. Data analysis was based on the comparative threshold cycle $\left(C_{\mathrm{t}}\right)$ method according to the manufacturer's instructions (Applied Biosystems), as previously described (Zhang et al. 2005).

\section{Immunofluorescence microscopy}

Cells $\left(10^{4}\right)$ were seeded on glass coverslips in growth medium. After $24 \mathrm{~h}$ of serum starvation, cells were incubated with
DHT (30 nM) or left untreated for $24 \mathrm{~h}$, then were stimulated or not with TNF $\alpha(10 \mathrm{ng} / \mathrm{ml})$ or with LPS $(100 \mathrm{ng} / \mathrm{ml})$ for $5 \mathrm{~h}$. Cells cultured in phenol red and serum-free medium were used as control. Immunostaining was performed as previously described (Penna et al. 2009) using primary Abs

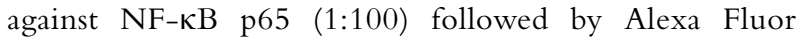
conjugated secondary Abs (1:200). Slides were then treated as reported elsewhere (Penna et al. 2009) and examined with a phase contrast microscope (Nikon Microphot-FX microscope, Nikon, Tokyo, Japan). Experiments were performed three times with different cell preparations.

\section{Statistical analysis}

Results are expressed as mean \pm s.E.M. Comparisons of means were performed with one-way ANOVA followed by unpaired two-sided Student's $t$-tests. $P<0.05$ was taken as significant. Correlations were assessed using Spearman's method. Stepwise multiple linear or logistic regressions were applied for multivariate analysis, whenever appropriate. Relative risk and 95\% confidence interval were calculated for association of categorical parameters.

All statistical analysis was performed on SPSS (SPSS, Inc., Chicago, IL, USA) for Windows 17.0. Values of half-maximal response inhibitory concentration $\left(\mathrm{IC}_{50}\right)$ as well as maximal inhibitory $\left(I_{\max }\right)$ effect were calculated by using the ALLFIT program (De Lean et al. 1978).

\section{Results}

\section{Association between inflammation and testosterone levels}

Histological features of inflammatory infiltrate specimens derived from $42 \mathrm{BPH}$ patients undergoing simple prostatectomy were analyzed blindly and scored according to a previously validated protocol (Nickel et al. 2001). The demographic and clinical characteristics of the patients analyzed are summarized in Table 1. Histopathological examination of $\mathrm{BPH}$ specimens demonstrated the presence of prostatic inflammation in all cases. The IS was higher in severe hypogonadal (testosterone $\leq 8 \mathrm{nM}$ ) than eugonadal (testosterone $>8 \mathrm{nM})$ patients $(P<0 \cdot 01$, Fig. 1 panel a). Accordingly, severe hypogonadism increased the risk of prostate inflammation by a factor of five, even after adjusting for age and body mass index (BMI; HR $=5 \cdot 7(1 \cdot 1-29 \cdot 4)$, $P<0 \cdot 05)$. In an age- and BMI-adjusted model, among the different factors composing the IS, the inflammatory infiltrate grade showed a significant, negative association with testosterone levels (adjusted $R=-0.35, P=0 \cdot 03$, Fig. 1 panel a, inset, and panel b). When patients were stratified according to current treatments, including $5 \alpha$-reductase inhibitors, no differences were found for inflammatory parameters (not shown).

Figure 1 shows histological patterns of prostatic inflammatory infiltrates in two representative patients (eugonadal: 
Table 1 Characteristics of the patients analyzed

\begin{tabular}{lc} 
& \multicolumn{1}{l}{ Values } \\
\cline { 2 - 2 } Clinical features & \\
Age (years) & \\
BMl & $26 \cdot 0 \pm 7 \cdot 4(51 \cdot 0-83 \cdot 0)$ \\
Metabolic syndrome features & $98 \cdot 7 \pm 8 \cdot 3(87 \cdot 0-131 \cdot 0)$ \\
Waist circumference $(\mathrm{cm})$ & $74 \cdot 3 \pm 6 \cdot 4(60-90)$ \\
DBP $(\mathrm{mmHg})$ & $131 \cdot 3 \pm 12 \cdot 8(110 \cdot 0-165 \cdot 0)$ \\
SBP $(\mathrm{mmHg})$ & $48 \cdot 4 \pm 5 \cdot 4(39 \cdot 0-61 \cdot 0)$ \\
HDL $(\mathrm{mg} / \mathrm{dl})$ & $112 \cdot 9 \pm 28 \cdot 3(62 \cdot 0-175 \cdot 0)$ \\
Triglycerides $(\mathrm{mg} / \mathrm{dl})$ & $100 \cdot 5 \pm 24 \cdot 3(70 \cdot 0-207 \cdot 0)$ \\
Glycemia $(\mathrm{mg} / \mathrm{dl})$ & \\
Hormonal features & $14 \cdot 8 \pm 5 \cdot 7(5 \cdot 4-31 \cdot 5)$ \\
Testosterone $(\mathrm{nM})$ & $8 \cdot 7 \pm 7 \cdot 2(1 \cdot 8-28 \cdot 0)$ \\
FSH (U/l) & $5 \cdot 6 \pm 3 \cdot 3(1 \cdot 4-13 \cdot 3)$ \\
LH (U/l) & \\
Pathology & \\
Prostate sample weight $(\mathrm{mg})$ & $76 \cdot 4 \pm 15 \cdot 5(40 \cdot 0-110 \cdot 0)$ \\
\cline { 2 - 2 }
\end{tabular}

BMI, body mass index; SBP, systolic blood pressure; DBP, diastolic blood pressure; $\mathrm{HDL}$, high-density lipoprotein. Data are expressed as mean \pm s.D.; the range is indicated in brackets.
Fig. 1 panels $\mathrm{c}$ and d, and hypogonadal: Fig. 1 panels e and f). In the eugonadal patient, a stromal scattering of individual inflammatory cells (typically lymphocytes) was documented (Fig. 1 panels c and d). By contrast, the prostate specimen from the hypogonadal patient displayed a marked stromal and periglandular inflammation, with intraepithelial and luminal inflammatory infiltrates causing glandular disruption (Fig. 1 panels e and f). CD45-positive cells were extensively present in both interductal stroma and intertwined within the epithelial glands in the hypogonadal patient (Fig. 1 panel f), while only scanty CD45-positive cells were present in the prostate specimen from the eugonadal subject (Fig. 1 panel d).

\section{DHT treatment inhibits basal secretion of proinflammatory cytokines/chemokines and growth factors by human BPH cells}

To investigate whether AR is involved in mediating the antiinflammatory effect of testosterone, the potent and selective AR ligand DHT was used. Experiments were performed in well-established stromal cell cultures isolated from $\mathrm{BPH}$ samples ( $n=6$ different preparations). We first measured cytokines, chemokines, and growth factors detected in culture supernatants of $\mathrm{BPH}$ cells (Fig. 2).
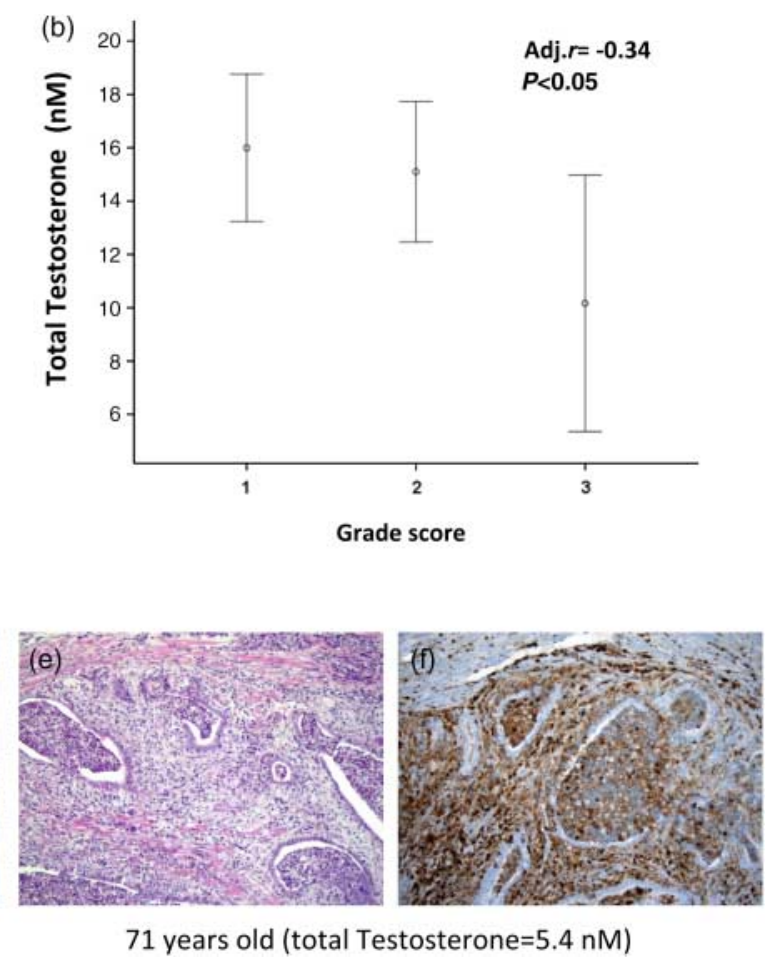

71 years old (total Testosterone $=5.4 \mathrm{nM}$ )
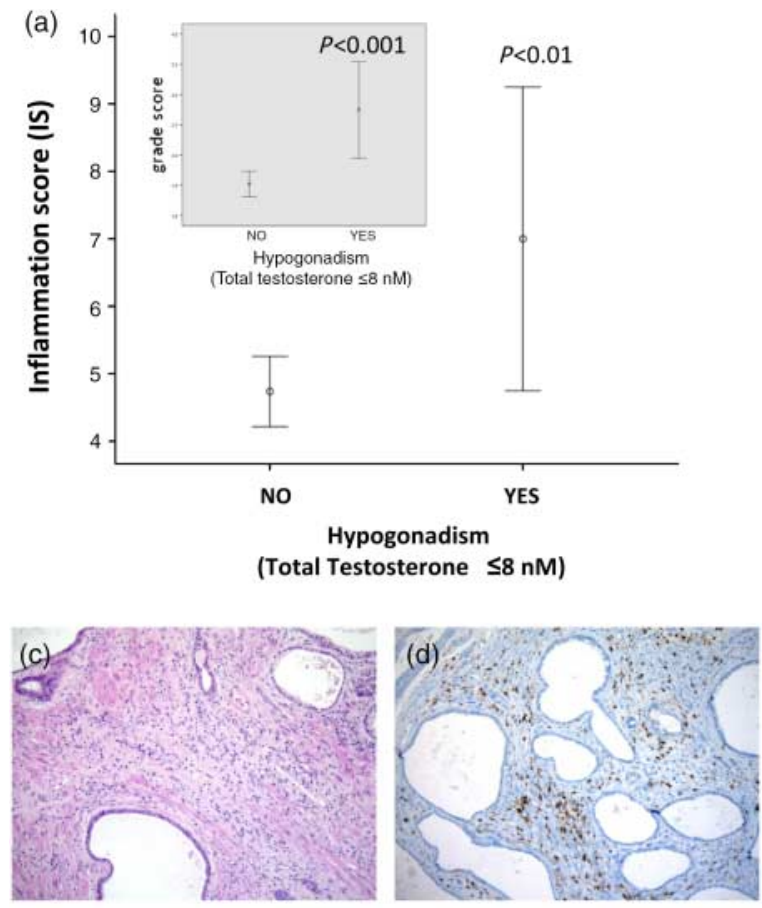

64 years old (total Testosterone $=21.3 \mathrm{nM}$ )

Figure 1 Histological features of intraprostatic inflammatory infiltrates in hypogonadal and eugonadal BPH subjects. (Panel a) Total inflammation score and grade (inset) of prostatic inflammation in hypogonadal (total testosterone $\leq 8 \mathrm{nM}$ ) and eugonadal (total testosterone $>8 \mathrm{nM}$ ) BPH subjects. (Panel b) Testosterone level as a function of intraprostatic inflammatory grade score. Inset indicates the age- and BMl-adjusted data. (Panels c-f) Frozen prostate samples from a representative eugonadal (panels c and d: total testosterone $=21 \cdot 3 \mathrm{nM}$ ) and hypogonadal (panels e and $\mathrm{f}$ : total testosterone $=5 \cdot 4 \mathrm{nM}$ ) patients were stained with $\mathrm{H} \& \mathrm{E}($ panels $\mathrm{C}$ and e) or with a specific $\mathrm{Ab}$ anti-pan leukocyte marker (CD45, panels $\mathrm{d}$ and f). Original magnification, $10 \times$. Full colour version of this figure available via http://dx.doi.org/10.1530/JOE-12-0142. 


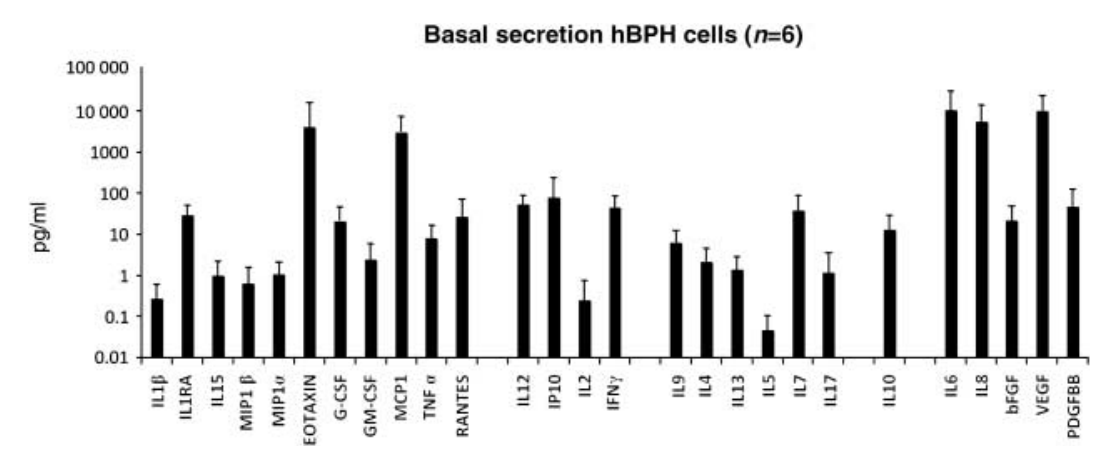

Figure 2 Cytokines, chemokines, and growth factor levels in hBPH cell cultures. Levels $(\mathrm{pg} / \mathrm{ml})$ of the indicated cytokines, chemokines, and growth factors were determined in culture supernatants by bead-based multiplex immunoassay. Data are expressed as mean \pm s.D. of basal secretion in six different preparations of hBPH cells obtained from prostate tissues of six different BPH patients.

VEGF, eotaxin, MCP-1 (CCL2), IL6, and IL8 were the most abundantly secreted products $(>1000 \mathrm{pg} / \mathrm{ml})$. Strikingly, after DHT treatment of BPH cells ( $30 \mathrm{nM}$ for $24 \mathrm{~h}$ ), a clear overall reduction in the secretion of inflammatory products was observed, with significant decreases seen for IL6, IL8, MCP-1, bFGF, IL7, IL9, INF- $\gamma$, IP-10 (CXCL10), IL12p75, and G-CSF (Fig. 3).

\section{DHT inhibits TNF $\alpha$-induced secretion of proinflammatory cytokines/chemokines and growth factors in hBPH cells}

The secretion of proinflammatory mediators and the effect of DHT (30 nM for $24 \mathrm{~h}$ ) were also studied in BPH cells after $\mathrm{TNF} \alpha$ priming $(10 \mathrm{ng} / \mathrm{ml}$ for $5 \mathrm{~h}$ ). TNF $\alpha$ upregulated basal secretion of IL8, IL6, IL9, IL12p75, IP-10, MCP-1, and bFGF (Fig. 4), with no effect on the other 20 cytokines and chemokines measured. Pretreatment with DHT significantly blunted TNF $\alpha$-induced secretion of IL8, IL6, IL9, IL12p75, IP-10, MCP-1, and bFGF (Fig. 4 panels a, b, c, $\mathrm{d}$, e, f and g). The effect of DHT was dose-dependent (shared $\mathrm{IC}_{50}=4.56 \pm 1.4 \times 10^{-11} \mathrm{M}$; Fig. 4 panel h), although with different $I_{\max }$ effects (Fig. 4 panel i).

\section{DHT inhibits NF- $\kappa B$ p 65 activation in TNF $\alpha$-stimulated $\mathrm{BPH}$ cells}

To better characterize the effect of DHT $(30 \mathrm{nM})$ on the inflammatory response of TNF $\alpha$-stimulated BPH cells, nuclear translocation of NF- $\kappa \mathrm{B}$ p 65 was studied. As assessed by immunofluorescence, in untreated $\mathrm{BPH}$ cells NF- $\mathrm{B}$ p 65 was totally retained in the cytoplasm (Fig. 5 panel e). TNF $\alpha$ induced a complete translocation of NF- $\mathrm{B}$ p 65 to the nucleus, which was inhibited $(56 \cdot 9 \pm 3 \cdot 8 \% ; P<0 \cdot 0001$ vs TNF $\alpha)$, but not normalized $(P<0 \cdot 001$ vs untreated $\mathrm{BPH}$ cells) by DHT (Fig. 5 panel e). Representative images are shown in Fig. 5 (panels a, b, c, and d). Accordingly, TNF $\alpha$ induced mRNA expression of the NF- $\kappa \mathrm{B}$ p 65 target gene COX2 (PTGS2; $P<0 \cdot 01$, Fig. 5 panel f) was significantly reduced by pretreatment with DHT $(P<0 \cdot 05)$.
DHT inhibits LPS-induced secretion of proinflammatory cytokines/chemokines and growth factors and $N F-\kappa B$ translocation and signaling in hBPH cells

We next tested the capacity of DHT to reduce the secretion of proinflammatory cytokines/chemokines and growth factor secretion in LPS-primed BPH cells. LPS treatment $(100 \mathrm{ng} / \mathrm{ml}$ for $48 \mathrm{~h})$ induced a significantly increased production of IL1 $\beta$, IL1RA, G-CSF, TNF $\alpha$, eotaxin, IFN- $\gamma$, IP-10, IL4, IL7, IL6, and IL8. Among these cytokines, only IL8, IL6, IL7, IP-10, TNF $\alpha$, and IL1RA were significantly reduced by pretreatment with DHT $(P<0 \cdot 05$; Fig. 6 panels a, b, c, d, e and f). Immunolocalization analysis demonstrated that LPS induced a 50\% translocation of NF- $\kappa \mathrm{B}$ p 65 to the nucleus, which was significantly inhibited $(15 \pm 3 \cdot 6 \% ; \quad P<0 \cdot 0001$ vs LPS), but not normalized $(P<0.001$ vs untreated BPH cells) by DHT preincubation

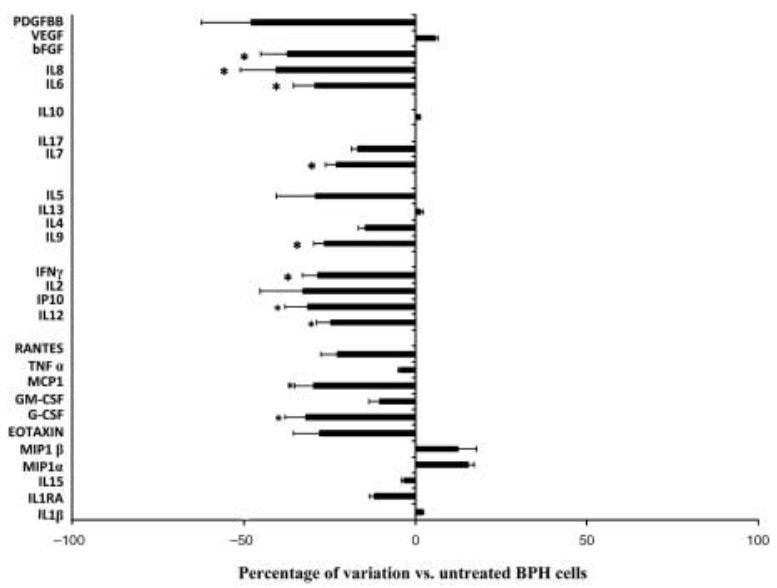

Figure 3 Effect of DHT treatment on cytokine/chemokine/growth factor secretion by BPH cells. hBPH cells were cultured for $24 \mathrm{~h}$ with serum-free medium alone (untreated) or DHT (30 nM). Culture supernatants were analyzed with a bead-based multiplex assay. Experiments were performed in triplicate using four different hBPH cell preparations. Data are expressed as percentage of variation vs untreated. ${ }^{*} P<0 \cdot 05$ vs untreated. 
(Fig. 6 panel g). As previously observed in TNF $\boldsymbol{\alpha}$-stimulated $\mathrm{BPH}$ cells, LPS-induced mRNA expression of COX2 was also significantly reduced by DHT (Fig. 6 panel h).

\section{Co-culture of BPH cells and activated $\mathrm{CD} 4^{+} T$ cell clones enhances production of proinflammatory cytokines/chemokines and growth factors}

As hBPH cells can act as APCs (Penna et al. 2009), we evaluated in co-culture experiments the capacity of hBPH cells to modulate cytokine production by T-cells (Fig. 7). We found that addition of $\mathrm{hBPH}$ cells to activated $\mathrm{CD} 4{ }^{+} \mathrm{T}$ cell clones resulted in significantly increased levels of several proinflammatory mediators, including IL1 $\beta$, IL15, TNF $\alpha$, eotaxin, G-CSF, MCP-1, and MIP-1 $\alpha$ (CCL3). IL1RA production was also significantly enhanced. A significant increase of the Th1-inducer IL12 and Th1-type chemokine IFN- $\gamma$-IP-10 was also observed, although IFN- $\gamma$ and IL2 production were not significantly modulated. Th2-type cytokines were also differentially modulated, with IL9 significantly increased and IL13 significantly decreased, whereas IL4 and IL5 were not significantly affected. By contrast, the T-cell growth factor IL7 (a)

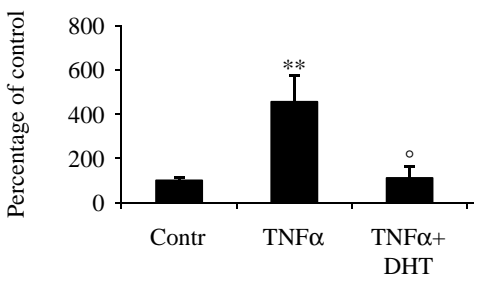

(d)

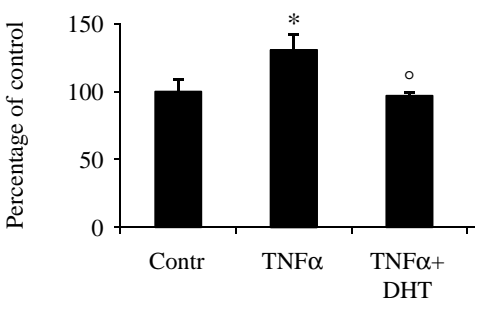

(g)

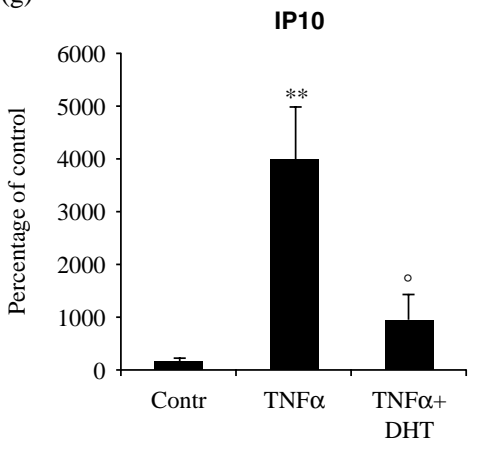

(b)

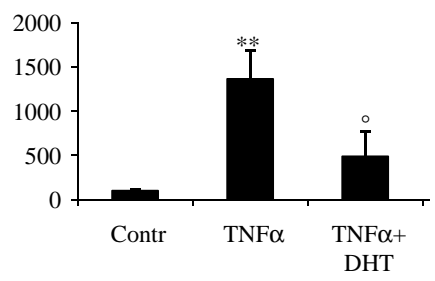

(e)

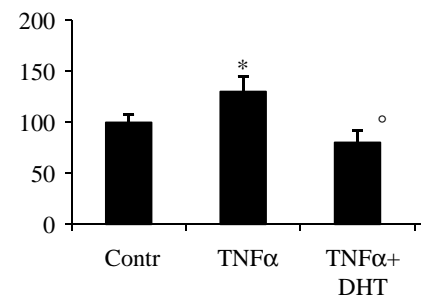

(c)

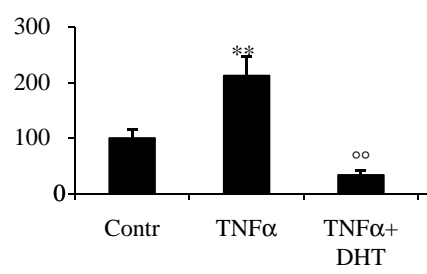

(f)

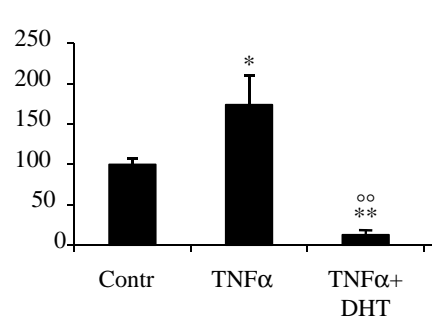

(h)

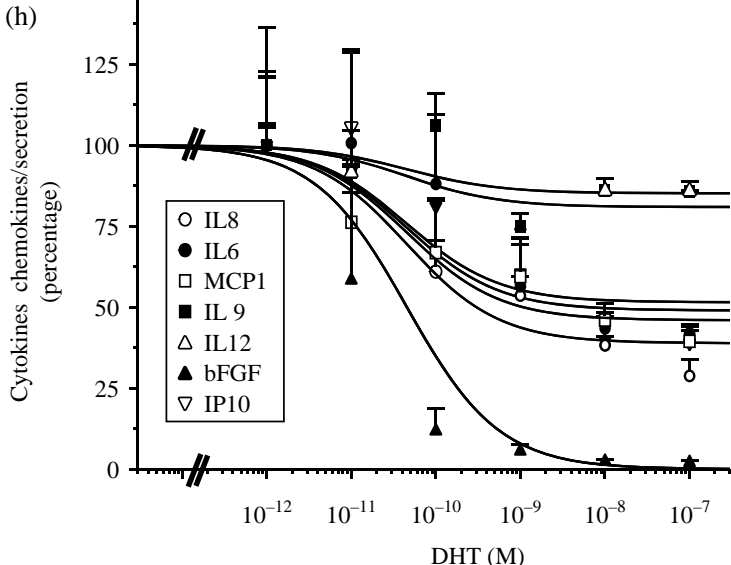

(i)

\begin{tabular}{|l|c|}
\hline & $I_{\max }$ \\
\hline IL6 & $48.5 \pm 5.6 \%$ \\
\hline MCP1 & $54.1 \pm 7.1 \%$ \\
\hline IL8 & $61.1 \pm 9.5 \%$ \\
\hline IP10 & $50.9 \pm 6.2 \%$ \\
\hline IL9 & $14.8 \pm 1.1 \%$ \\
\hline IL12(p70) & $19.1 \pm 1.4 \%$ \\
\hline bFGF & $100 \pm 0.8 \%$ \\
\hline
\end{tabular}

Figure $4 \mathrm{DHT}$ inhibits TNF $\alpha$-induced secretion of cytokines, chemokines, and growth factors by hBPH cells. hBPH cells were stimulated with TNF $\alpha(10 \mathrm{ng} / \mathrm{ml}$ for $5 \mathrm{~h}$ ) with or without preincubation with DHT (30 nM for $24 \mathrm{~h}$ ). (Panels a, b, c, d, e, f and g). Culture supernatants were analyzed for production of the indicated cytokines, chemokines, and growth factors. The data represent the mean \pm S.E.M. of four independent experiments performed in triplicate and are reported as percentage of untreated cells (control). ${ }^{*} P<0 \cdot 05,{ }^{* *} P<0 \cdot 01 \mathrm{vs}$ control; ${ }^{\circ} P<0.05,{ }^{\circ} P<0.01$ vs TNF $\alpha$. (Panel h) Inhibitory effect of increasing concentrations of DHT (1 pM-100 nM) on TNF $\alpha$-induced cytokine, chemokine, or growth factor secretion by hPBH cells. Ordinate: secretion of the indicated cytokines, chemokines, and growth factors induced by TNF $\alpha(10 \mathrm{ng} / \mathrm{ml}$ for $5 \mathrm{~h})$, expressed as percentage of the effect of TNF $\alpha$ alone. Abscissa: molar concentrations of DHT. The data represent the mean \pm S.E.M. of four independent experiments performed in triplicate. The relative half-maximal response $\mathrm{IC}_{50}$ value is reported in the text, while relative $I_{\max }$ effects are reported in panel i. 
(a)

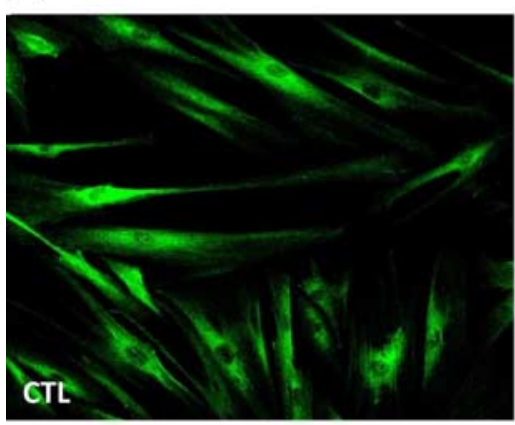

(d)

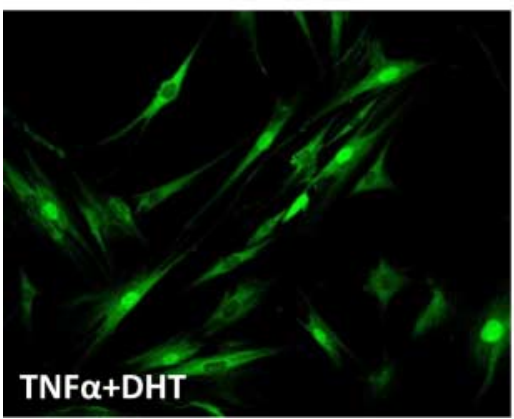

(b)

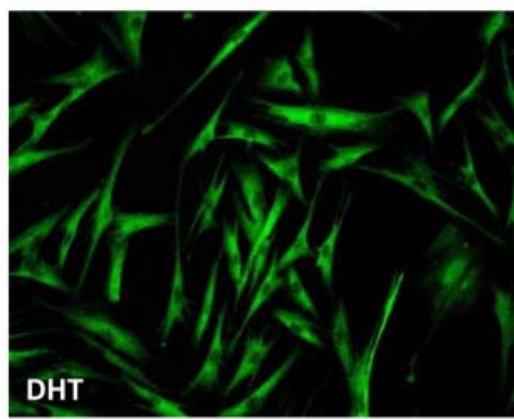

(e)

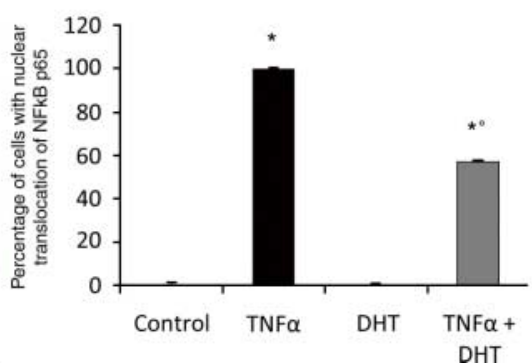

(c)

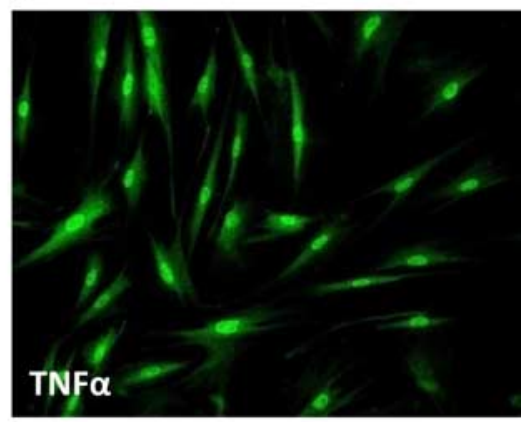

(f)

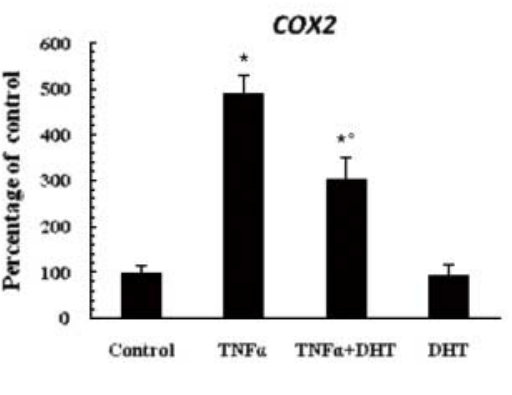

Figure 5 DHT inhibits NF-KB p65 nuclear translocation in hBPH cells. hBPH cells were stimulated with TNF $\alpha(10 \mathrm{ng} / \mathrm{ml}$ for $5 \mathrm{~h})$ with or without preincubation with DHT (30 nM for $24 \mathrm{~h}$ ). After washing, hBPH cells were fixed and stained with anti-NF-kB p65 Ab. Cells were analyzed by fluorescence microscopy. Images of panels $\mathrm{a}, \mathrm{b}, \mathrm{c}$ and $\mathrm{d}$ are representative from one of three experiments performed (magnification 10X). (Panel e) Bar graph shows the number of cells with nuclear localization of NF-kB expressed in percentage of total cells. The data represent the mean \pm s.E.M. of three independent experiments performed in triplicate. (Panel f) mRNA expression of COX2 was evaluated using qRT-PCR in hBPH cells untreated (control) and TNF $\alpha$ primed, with or without preincubation with DHT (30 nM for $24 \mathrm{~h}$ ). Data were calculated according to comparative $C_{\mathrm{t}}$ method using $18 \mathrm{~S} \mathrm{rRNA}$ subunit as the reference gene for normalization. Results are expressed as percentage of control and are reported as mean \pm S.E.M. of three independent experiments performed in triplicate. ${ }^{*} P<0 \cdot 001$ vs control; ${ }^{\circ} P<0 \cdot 0001 \mathrm{vs} \mathrm{TNF} \alpha$. Full colour version of this figure available via http://dx.doi.org/10. 1530/JOE-12-0142.

and the Th17-specific cytokine IL17 were both significantly increased. In keeping with the overall proinflammatory effects of hBPH cells on cytokine production by T-cells, the antiinflammatory cytokine IL10 was significantly inhibited. Interestingly, a series of factors promoting $\mathrm{BPH}$ cell growth, such as IL8, IL6, bFGF, VEGF, and PDGFBB, were markedly enhanced by co-cultures.

\section{Co-culture of DHT-pretreated BPH cells and activated $\mathrm{CD}^{+} \mathrm{T}$ cell clones inhibit secretion of proinflammatory cytokine/chemokines and growth factors}

When activated $\mathrm{CD}^{+}{ }^{+} \mathrm{T}$ cell clones were cultured with DHT-primed (30 nM for $24 \mathrm{~h}$ ) hBPH cells, secretion of several proinflammatory factors was significantly affected (Fig. 8). In general, production of proinflammatory mediators was blunted, with a significant reduction observed for MCP-1, MIP-1 $\alpha$, and MIP-1 $\beta$. Cytokine production by effector T-cells was consistently reduced, with significant decreases seen for IL2, IL4, IL13, and IL17. Also production of the Th1-recruiting chemokine IP-10 was significantly decreased. By contrast, IL10 was significantly increased, consistent with the antiinflammatory activity of DHT. In line with the antiinflammatory properties displayed by DHT, factors promoting hBPH cell growth were mostly decreased, with significant effects seen for IL8, IL6, and bFGF, whereas VEGF secretion was increased.

\section{DHT-pretreated $\mathrm{BPH}$ cells inhibit proliferation of activated $\mathrm{CD}^{+} \mathrm{T}$ cells}

Proliferation of $\mathrm{CD}^{+}{ }^{+} \mathrm{T}$ cell clones, as measured by $\left[{ }^{3} \mathrm{H}\right]$ thymidine incorporation, was significantly increased by activation with anti-CD3 $\mathrm{Ab}(P<0 \cdot 05)$, while it was not affected by the addition of irradiated $\mathrm{hBPH}$ cells (Fig. 9). However, when hBPH cells were pretreated with DHT (30 nM for $24 \mathrm{~h}$ ), a significant inhibition of T-cell proliferation was observed $(P<0 \cdot 01$; Fig. 9$)$. 
(a)

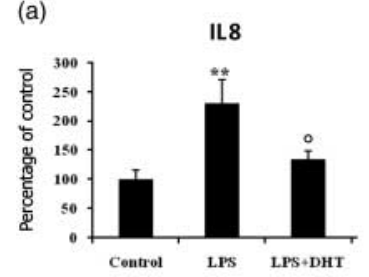

(d)
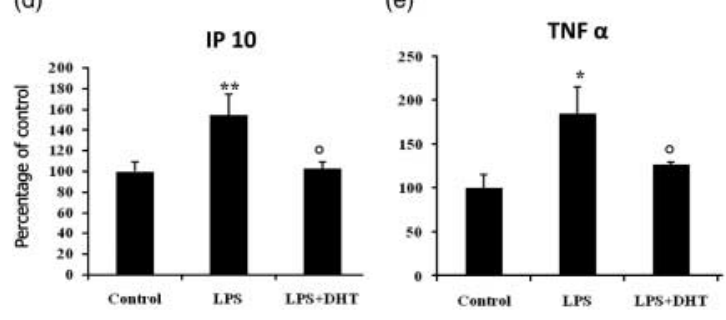

(c)

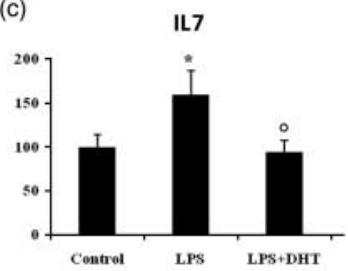

(f)

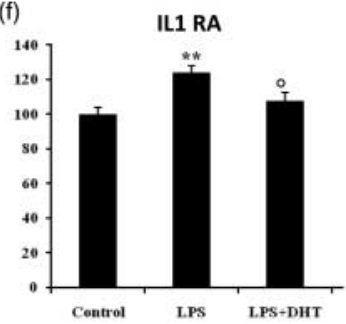

(g)

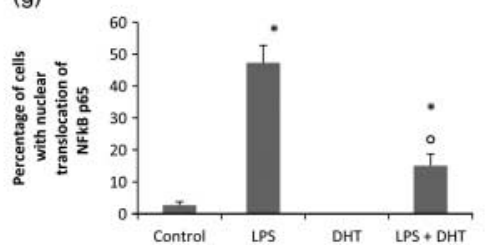

(h)

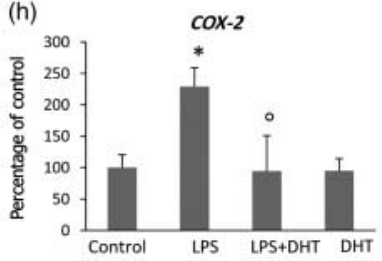

Figure 6 DHT inhibits LPS-induced inflammatory response in BPH cells. BPH cells were stimulated with LPS $(100 \mathrm{ng} / \mathrm{ml}$, for $48 \mathrm{~h}$ ) with or without preincubation with DHT (30 nM for $24 \mathrm{~h}$ ). Cell culture supernatants were analyzed for production of the indicated cytokines, chemokines, and growth factors (panels $a, b, c, d$, e and $f$ ). The data represent the mean \pm S.E.M. of four independent experiments performed in triplicate. ${ }^{*} P<0 \cdot 05,{ }^{* *} P<0 \cdot 01$ vs control; ${ }^{\circ} P<0.05$ vs LPS. (Panel g) NF- $\kappa$ B p65 nuclear translocation in BPH cells stimulated by LPS $(100 \mathrm{ng} / \mathrm{ml}$, for $5 \mathrm{~h})$, expressed in percentage of total cells. The data represent the mean \pm S.E.M. of four independent experiments performed in triplicate. $\left(* P<0 \cdot 001\right.$ vs untreated hBPH cells; ${ }^{\circ} P<0 \cdot 0001$ vs LPS). (Panel h) mRNA expression of COX2 was evaluated using qRT-PCR in hBPH cells untreated (control) and LPS-primed pretreated or not with DHT (30 nM, for $24 \mathrm{~h}$ ). Data were calculated according to the comparative $C_{\mathrm{t}}$ method using $18 \mathrm{~S}$ rRNA subunit as the reference gene for normalization. Results are expressed in percentage of control and are reported as mean \pm S.E.M. of three independent experiments performed in triplicate. ${ }^{*} P<0 \cdot 001$ vs control, ${ }^{\circ} P<0 \cdot 0001$ vs LPS.

\section{Discussion}

Results in this study demonstrate, for the first time, that AR activation exerts a direct antiinflammatory effect on human stromal prostate cells, thus inhibiting their potential to induce and sustain autoimmune and inflammatory responses.

Chronic intraprostatic inflammation and subsequent chronic tissue remodeling are determinant factors in the development and progression of prostatic diseases, including BPH (see Kramer et al. (2007), Fibbi et al. (2010b) and Schauer \& Rowley (2011) for reviews). A possible hormonal basis for prostate inflammation is suggested by preclinical studies in animal models, demonstrating that hypogonadism induced surgically (Robinette 1988, Desai et al. 2004, Quintar et al. 2006, Meng et al. 2011) or by HFD administration (Vignozzi et al. 2012) exacerbate prostate inflammation and that exogenous testosterone can counteract this effect. In particular, we have shown in a rabbit model that testosterone supplementation can prevent HFD-induced prostatic alterations, including inflammation, tissue remodeling, and hypoxia (Vignozzi et al. 2012).

In the present study, we sought to provide evidence supporting the hypothesis that low androgen levels could enhance inflammatory responses in the human prostate. Hence, we first retrospectively examined the histological features of inflammatory infiltrates in prostatectomy specimens derived from a cohort of BPH patients. Even after adjusting for confounding factors, hypogonadism was associated with a fivefold increased risk of intraprostatic inflammation, which was also more severe than that observed in eugonadal BPH patients. Although it is historically assumed that high testosterone induces prostate overgrowth, most observational studies failed to find correlations between circulating testosterone levels and BPH: in fact, no clear correlation with serum PSA or prostate volume across the normal testosterone range has been shown (Liu et al. 2007). In addition, the notion that intraprostatic $5 \alpha$-reductase activity, which is responsible for converting the bulk of testosterone 


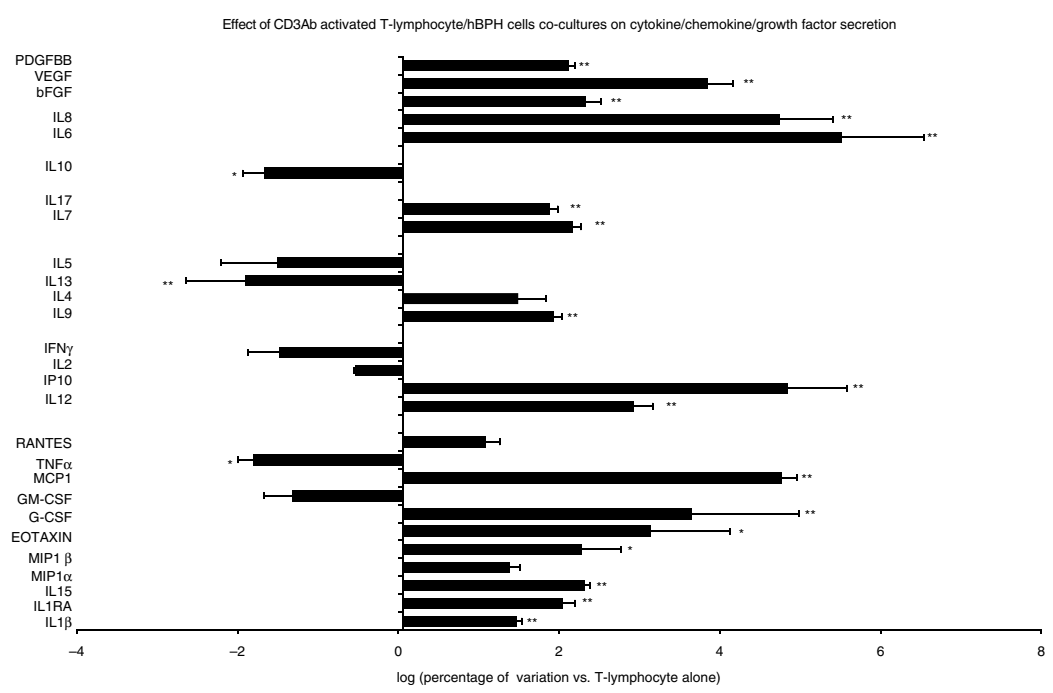

Figure 7 Secretion of cytokines, chemokines, and growth factor levels by hBPH cell/CD4 ${ }^{+}$ $\mathrm{T}$ cell co-cultures. Concentration $(\mathrm{pg} / \mathrm{ml})$ of the indicated cytokines, chemokines, and growth factors were determined in the supernatants by bead-based multiplex immunoassay. Data are expressed as log (percentage of variation vs activated $\mathrm{CD} 4{ }^{+} \mathrm{T}$ cells alone) and reported as mean \pm S.E.M. of three individual experiments. ${ }^{*} P<0 \cdot 05,{ }^{* *} P<0 \cdot 001$ vs $\mathrm{CD} 4^{+}$T cells.

into DHT, is altered in the BPH tissues is contentious (Isaacs et al. 1983, Bartsch et al. 1990). However, it could be hypothesized that intraprostatic level of DHT could be more important than the level of serum testosterone for the growth of the prostate (Isaacs et al. 1983), thus explaining this lack of association between serum testosterone level and prostate overgrowth. In contrast, some uncontrolled studies have reported a gradual improvement in the International Prostate Symptom Score (IPSS) following long-term testosterone therapy in men with hypogonadism and/or metabolic syndrome (MetS) (see review in Buvat et al. (2010)). A small randomized controlled trial with testosterone enanthate in 23 men with BPH tends to support these findings, with a significant decrease in the IPSS score, maximum flow rate, and voided volume in the testosterone group but not in the 23 untreated controls (Shigehara et al. 2011). However, in the present sample we did not find any difference in inflammation in $\mathrm{BPH}$ specimens from subjects treated or not with $5 \alpha$-reductase inhibitors.

To better investigate whether androgens could directly suppress prostate inflammatory responses, we performed in vitro studies in human prostatic stromal cell cultures using the potent and selective AR ligand DHT. We have previously demonstrated the ability of hBPH cells to function as APCs, and to actively contribute to the organ-specific inflammatory process (Penna et al. 2009). Herein, we confirm that hBPH stromal cells secrete several proinflammatory and growth factors. Among them, IL8, IL6, MCP-1, VEGF, and eotaxin were the most abundantly secreted. A similar pattern of cytokine and chemokine secretion was previously described in seminal plasma of patients affected by BPH (Penna et al. 2007). In particular, seminal plasma IL8 was identified as a reliable surrogate marker of prostatic inflammatory diseases and $\mathrm{BPH}$, thanks to the fact that its level positively correlated with serum PSA, with prostatitis symptom score (Penna et al. 2007), and with ultrasonographic features of prostate inflammation (Lotti et al. 2011). The present data show secretion by stromal hBPH cells of many cytokines, chemokines, and growth factors induced by inflammatory stimuli, including TNF $\alpha$, LPS, or activated $\mathrm{CD} 4^{+} \mathrm{T}$ cells. Secretion of IL8 and IL6 was markedly upregulated, as was production of bFGF, suggesting that an activated immune system might sustain prostate overgrowth. IL8, a primary cytokine in the recruitment of neutrophils into the inflammatory sites, showed also a potent proliferative action in prostate. Indeed, IL8 induced stromal BPH cell overgrowth by directly promoting the fibroblast-to-myofibroblast transdifferentiation and by indirectly stimulating secretion of bFGF, which acts as a potent prostatic growth factor. Similar to IL8, IL6 directly promotes stromal cell proliferation in an autocrine manner (see Fibbi et al. (2010b) for a review). The increased production of several chemokines, including IP-10, IL8, MCP-1, MIP-1 $\alpha$, and MIP-1 $\beta$ in co-cultures of BPH cells with activated $\mathrm{CD} 4{ }^{+} \mathrm{T}$ cell clones suggested the capacity of $\mathrm{BPH}$ cells to recruit Th1 cells and other immune cells into the inflamed prostate. A concomitant increase of IL1 $\beta$, IL1RA, and IL15, cytokines described to be highly upregulated in BPH (see Kramer et al. (2007) for a review) has also been observed.

Our data also demonstrate that hBPH cells can influence $\mathrm{CD} 4{ }^{+} \mathrm{T}$ cell activation, modulating their phenotype. When activated $\mathrm{CD} 4{ }^{+} \mathrm{T}$ cell clones were co-cultured with $\mathrm{hBPH}$ cells, a significant increase of a Th1 inducer (IL12), a Th1recruiting chemokine (IP-10), a Th2-type cytokine (IL9), and a Th17-specific cytokine (IL17) was observed. In addition, IL7, a crucial cytokine for survival and expansion of Th17 cells 


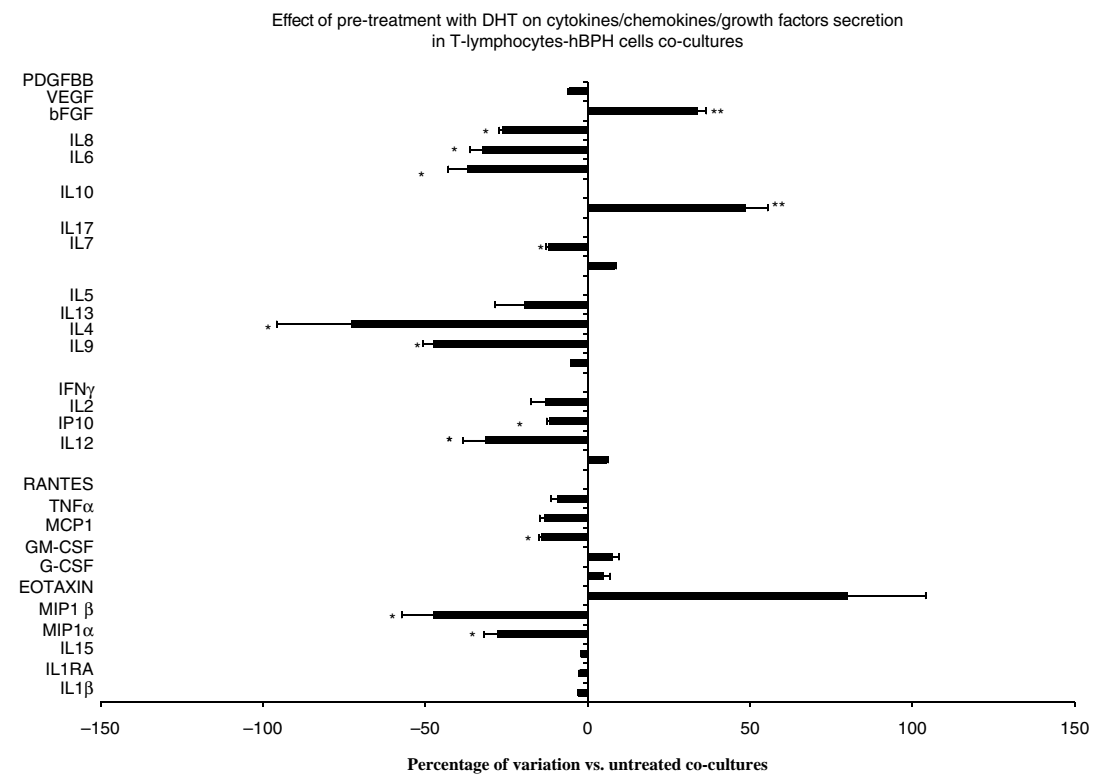

Figure 8 Secretion of cytokines, chemokines, and growth factor levels by DHT-treated $\mathrm{hBPH}$ cell/CD4 ${ }^{+} \mathrm{T}$ cell co-cultures. Concentrations $(\mathrm{pg} / \mathrm{ml})$ of the indicated cytokines, chemokines, and growth factors were determined in the supernatants by bead-based multiplex immunoassay. Data are expressed as percentage of variation vs untreated hBPH cell/CD4 ${ }^{+} \mathrm{T}$ cell co-cultures and reported as mean \pm S.E.M. of three individual experiments. ${ }^{*} P<0 \cdot 05,{ }^{* *} P<0 \cdot 001$ vs untreated $\mathrm{hBPH} / \mathrm{CD} 4{ }^{+} \mathrm{T}$ cell co-cultures.

in autoimmune disease models (Kanai et al. 2009, Liu et al. 2010) was also increased. Concomitantly, a marked decrease of the antiinflammatory cytokine IL10 was also observed.

The most striking finding of the present study is that activation of AR by DHT markedly suppresses the inflammatory response and secretion of growth factors in $\mathrm{hBPH}$ cells, thus suggesting that stromal cell AR plays an important role in maintaining adult prostate homeostasis. This is in agreement with the observation that the selective ablation of AR in mouse prostate stromal cells causes a diffuse stromal hyperplasia mostly characterized by infiltration of leukocytes (neutrophils and monocytes) in adult prostate gland (Welsh et al. 2011).

The prevalent inhibitory effect of DHTwas observed in IL8 and bFGF secretion, both in basal and stimulated conditions. Interestingly, this antiinflammatory effect of DHT was exerted at very low concentrations $\left(10^{-11} \mathrm{~mol} / \mathrm{l}\right)$, roughly corresponding to the $K_{\mathrm{d}}$ of DHT for the AR in hBPH cells (Crescioli et al. 2003).

In the present study we also demonstrated that DHT-primed hBPH cells co-cultures with $\mathrm{CD} 4{ }^{+} \mathrm{T}$ cell clones caused a reduction in cytokines produced by effector T-cells and an increase in IL10 production. This suggests that DHT could play a broad antiinflammatory role on $\mathrm{CD} 4{ }^{+} \mathrm{T}$ helper cells. Moreover, DHT inhibited the production of IL2, T-cell growth and differentiation (see Liao et al. (2011)), thus explained the reduced proliferation of $\mathrm{CD}^{+} \mathrm{T}$ cell clones in culture with DHT-primed hBPH cells.
The mechanisms by which DHT exerts its antiinflammatory effects are not completely understood. We demonstrate that DHT inhibits NF- $\kappa \mathrm{B}$ activation, a master transcription factor in inflammation, as evidenced by its reduced nuclear translocation and by the decreased expression of COX2. A similar antiinflammatory effect has been described also in human endothelial cells, where DHT or testosterone

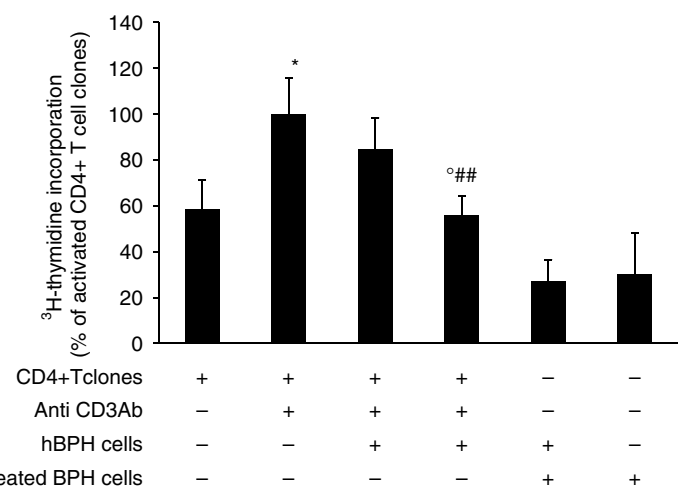

Figure 9 Proliferation of activated $\mathrm{CD}^{+}{ }^{+} \mathrm{T}$ cell clones in the presence of irradiated hBPH cells pretreated or not with DHT. Irradiated (9000 rads) hBPH cells, pretreated or not with $30 \mathrm{nM}$ $\mathrm{DHT}$ for $24 \mathrm{~h}$, were co-cultured with $\mathrm{CD} 4{ }^{+} \mathrm{T}$ cell clones for $48 \mathrm{~h}$, then proliferation was measured by $\left[{ }^{3} \mathrm{H}\right]$ thymidine incorporation. Data represent the mean \pm s.E.M. of three independent experiments ${ }^{*} P<0.05$ vs not-activated $\mathrm{CD} 4{ }^{+} \mathrm{T}$ cell clones alone; ${ }^{\# \#} P<0.01$ vs activated $\mathrm{CD} 4^{+} \mathrm{T}$ cell clones; ${ }^{\circ} \mathrm{P}<0 \cdot 05$ vs activated $\mathrm{CD} 4^{+} \mathrm{T}$ cell clones co-cultured with hBPH cells. 
decreased $\mathrm{TNF} \boldsymbol{\alpha}$-induced inflammatory response through the inhibition of NF- $\mathrm{KB}$ signaling pathway (Hatakeyama et al. 2002, Norata et al. 2006).

Alternative, direct antiinflammatory mechanisms are also plausible, as suggested by a specific androgen response element present in genes related to inflammatory and proliferative response, such as IL6, described in rat prostate epithelial cells (Asirvatham et al. 2006).

In conclusion, our data demonstrate that DHT exerts an immune regulatory role on human prostatic stromal cells, inhibiting their potential to actively induce and/or sustain autoimmune and inflammatory responses. The prostate is an immunocompetent organ, not only because it is populated by resident inflammatory cells, including $\mathrm{T}$ - and B-lymphocytes, macrophages, and mast cells (De Marzo et al. 2007, Fibbi et al. 2010a,b), but also because stromal prostatic cells can secrete several proinflammatory cytokines and are able to recruit and activate $\mathrm{CD} 4{ }^{+}$cells into the inflamed prostate. Under most conditions, this immune competence of the prostate would be beneficial to the host. However, in some situations, an immune response toward a Th1/Th17 cytokine profile might lead to the development of chronic immune-mediated tissue destruction and fibromyomatosus growth, as observed in the pathogenesis of BPH. Interestingly, our data indicate that AR signaling might restrain, rather than facilitate, prostate inflammation.

Thus, DHT should be considered more a friend than a foe of prostate cells, consistent with the observation that prostate glands from hypogonadal subjects are more inflamed than those from eugonadal ones. Interventional studies aimed at evaluating the antiinflammatory effects of testosteronereplacement therapy in hypogonadal subjects with $\mathrm{BPH}$ are therefore warranted.

\section{Declaration of interest}

L V, I C, A M, P C, S F, M G, M C, F L, L L, M-P P, G N, and R S have no conflicts of interest that could be perceived as prejudicing the impartiality of the research reported and have nothing to declare. $M$ consultant for Bayer Pharma AG, Germany, and Eli-Lilly Indianapolis, Indiana. L A is an employee of Intercept Pharmaceuticals 18 Desbrosses Street, New York, NY 10013, USA

\section{Funding}

The study was supported by PRIN (Programmi di ricerca di Rilevante Interesse Nazionale) funds by the Italian Minister of University, Research and Instruction (prot number: 2009WLNXNT_002), by FIRB (Programma Futuro in Ricerca) funds by the Italian Minister of University, Research and Instruction (prot number: RBFR10VJ56_002).

\section{Acknowledgements}

The authors thank Mario Rotondi (Unit of Internal Medicine and Endocrinology Fondazione Salvatore Maugeri IRCCS, University of Pavia, 27100 Pavia, Italy) for his helpful suggestions and comments.

\section{References}

Asirvatham AJ, Schmidt M, Gao B \& Chaudhary J 2006 Androgens regulate the immune/inflammatory response and cell survival pathways in rat ventral prostate epithelial cells. Endocrinology 147 257-271. (doi:10.1210/en. 2005-0942)

Azadzoi KM, Tarcan T, Siroky MB \& Krane RJ 1999 Atherosclerosis-induced chronic ischemia causes bladder fibrosis and non-compliance in the rabbit. Journal of Urology 161 1626-1635. (doi:10.1016/S0022-5347(05)68995-1)

Bartsch W, Klein H, Schiemann U, Bauer HW \& Voigt KD 1990 Enzymes of androgen formation and degradation in the human prostate. Annals of the New York Academy of Sciences 595 53-66. (doi:10.1111/j.1749-6632.1990. tb34282.x)

Buvat J, Maggi M, Gooren L, Guay AT, Kaufman JM, Morgentaler A, Schulman C, Tan HM, Torres LO, Yassin A et al. 2010 Endocrine aspects of male sexual dysfunctions. Journal of Sexual Medicine 7 1627-1656. (doi:10.1111/j.1743-6109.2010.01780.x)

Crescioli C, Maggi M, Vannelli GB, Luconi M, Salerno R, Barni T, Gulisano M, Forti G \& Serio M 2000 Effect of a vitamin D3 analog on keratinocyte growth factor-induced cell proliferation in benign prostate hyperplasia. Journal of Clinical Endocrinology and Metabolism 85 2576-2583. (doi:10.1210/jc.85.7.2576)

Crescioli C, Ferruzzi P, Caporali A, Mancina R, Comerci A, Muratori M, Scaltriti M, Vannelli GB, Smiroldo S, Mariani R et al. 2003 Inhibition of spontaneous and androgen-induced prostate growth by a nonhypercalcemic calcitriol analog. Endocrinology 144 3046-3057. (doi:10.1210/en.2002-0210)

De Lean A, Munson PJ \& Rodbard D 1978 Simultaneous analysis of famiglie of sigmoidal curves: application to biomassa, radioligand assay, and physiological dose-response curves. American Journal of Physiology 235 97-102.

De Marzo AM, Platz EA, Sutcliffe S, Xu J, Grönberg H, Drake CG, Nakai Y, Isaacs WB \& Nelson WG 2007 Inflammation in prostate carcinogenesis. Nature Reviews. Cancer 7 256-269. (doi:10.1038/nrc2090)

Desai KV, Michalowska AM, Kondaiah P, Ward JM, Shih JH \& Green JE 2004 Gene expression profiling identifies a unique androgen-mediated inflammatory/immune signature and a PTEN (phosphatase and tensin homolog deleted on chromosome 10)-mediated apoptotic response specific to the rat ventral prostate. Molecular Endocrinology 18 2895-2907. (doi:10.1210/me.2004-0033)

Fibbi B, Morelli A, Vignozzi L, Filippi S, Chavalmane A, De Vita G, Marini M, Gacci M, Vannelli GB, Sandner P et al. 2010a Characterization of phosphodiesterase type 5 expression and functional activity in the human male lower urinary tract. Journal of Sexual Medicine 7 59-69. (doi:10.1111/j. 1743-6109.2009.01511.x)

Fibbi B, Penna G, Morelli A, Adorini L \& Maggi M 2010b Chronic inflammation in the pathogenesis of benign prostatic hyperplasia. International Journal of Andrology 33 475-488. (doi:10.1111/j.1365-2605.2009.00972.x)

Filippi S, Vignozzi L, Morelli A, Chavalmane AK, Sarchielli E, Fibbi B, Saad F, Sandner P, Ruggiano P, Vannelli GB et al. 2009 Testosterone partially ameliorates metabolic profile and erectile responsiveness to PDE5 inhibitors in an animal model of male metabolic syndrome. Journal of Sexual Medicine 6 3274-3288. (doi:10.1111/j.1743-6109.2009.01467.x)

Hatakeyama H, Nishizawa M, Nakagawa A, Nakano S, Kigoshi T \& Uchida K 2002 Testosterone inhibits tumor necrosis factor-alpha-induced vascular cell adhesion molecule-1 expression in human aortic endothelial cells. FEBS Letters 530 129-132. (doi:10.1016/S0014-5793(02)03440-3)

Isaacs JT, Brendler CB \& Walsh PC 1983 Changes in the metabolism of dihydrotestosterone in the hyperplastic human prostate. Journal of Clinical Endocrinology and Metabolism 56 139-146. (doi:10.1210/jcem-56-1-139)

Issa MM \& Regan TS 2007 Medical therapy for benign prostatic hyperplasia present and future impact. American Journal of Managed Care 1 S4-S9.

Kanai T, Nemoto Y, Kamada N, Totsuka T, Hisamatsu T, Watanabe M \& Hibi T 2009 Homeostatic (IL-7) and effector (IL-17) cytokines as distinct but complementary target for an optimal therapeutic strategy in inflammatory bowel disease. Current Opinion in Gastroenterology 25 306-313. (doi:10.1097/MOG.0b013e32832bc627)

Kozlowski R, Kershen RT, Siroky MB, Krane RJ \& Azadzoi KM 2001 Chronic ischemia alters prostate structure and reactivity in rabbits. Journal of Urology 165 1019-1026. (doi:10.1016/S0022-5347(05)66595-0) 
Krajewska M, Banares S, Zhang EE, Huang X, Scadeng M, Jhala US, Feng GS \& Krajewski S 2008 Development of diabesity in mice with neuronal deletion of Shp2 tyrosine phosphatase. American Journal of Pathology 172 1312-1324. (doi:10.2353/ajpath.2008.070594)

Kramer G, Mitteregger D \& Marberger M 2007 Is benign prostatic hyperplasia (BPH) an immune inflammatory disease? European Urology 51 1202-1216. (doi:10.1016/j.eururo.2006.12.011)

Lédée N, Lombroso R, Lombardelli L, Selva J, Dubanchet S, Chaouat G, Frankenne F, Foidardart JM, Maggi E, Romagnani S et al. 2008 Cytokines and cemokines in follicular fluids and potential of the corresponding embryo: the role of granulocyte colony-stimulating factor. Human Reproduction 23 2001-2009. (doi:10.1093/humrep/den192)

Liao W, Lin JX \& Leonard WJ 2011 IL-2 family cytokines: new insights into the complex roles of IL-2 as a broad regulator of T helper cell differentiation. Current Opinion in Immunology 23 598-604. (doi:10.1016/j.coi.2011.08.003)

Liu CC, Huang SP, Li WM, Wang CJ, Chou YH, Li CC, Huang CH \& Wu WJ 2007 Relationship between serum testosterone and measures of benign prostatic hyperplasia in aging men. Urology 70 677-680. (doi:10.1016/j.urology.2007.05.025)

Liu X, Leung S, Wang C, Tan Z, Wang J, Guo TB, Fang L, Zhao Y, Wan B, Qin X et al. 2010 Crucial role of interleukin-7 in T helper type 17 survival and expansion in autoimmune disease. Nature Medicine 16 191-197. (doi:10.1038/nm.2077)

Lotti F, Corona G, Colpi GM, Filimberti E, Degli Innocenti S, Mancini M, Baldi E, Noci I, Forti G, Adorini L et al. 2011 Elevated body mass index correlates with higher seminal plasma interleukin 8 levels and ultrasonographic abnormalities of the prostate in men attending an andrology clinic for infertility. Journal of Endocrinological Investigation 34 336-342.

Meng J, Mostaghel EA, Vakar-Lopez F, Montgomery B, True L \& Nelson PS 2011 Testosterone regulates tight junction proteins and influences prostatic autoimmune responses. Hormones \& Cancer 2 145-156. (doi:10.1007/ s12672-010-0063-1)

Morelli A, Comeglio P, Filippi S, Sarchielli E, Cellai I, Vignozzi L, Yehiely-Cohen R, Maneschi E, Gacci M, Carini M et al. 2012 Testosterone and farnesoid X receptor agonist INT-747 ounteract high fat diet-induced bladder alterations in a rabbit model of metabolic syndrome. Journal of Steroid Biochemistry and Molecular Biology (http://dx.doi.org/10.1016/j.jsbmb.2012.02.007)

Nickel JC, True LD, Krieger JN, Berger RE, Boag AH, Young ID \& participating members of the North American Chronic Prostatitis Collaborative Research Network and the International Prostatitis Collaborative Network 2001 Consensus development of a histopathological classification system for chronic prostatic inflammation. British Journal of Urology International 87 797-805. (doi:10.1046/j.1464-410x.2001.02193.x)

Nickel JC, Roehrborn CG, O'leary MP, Bostwick DG, Somerville MC \& Rittmaster RS 2007 Examination of the relationship between symptoms of prostatitis and histological inflammation: baseline data from the REDUCE chemoprevention trial. Journal of Urology 178 896-900. (doi:10.1016/j.juro. 2007.05.041)

Nickel JC, Roehrborn CG, O'Leary MP, Bostwick DG, Somerville MC \& Rittmaster RS 2008 The relationship between prostate inflammation and lower urinary tract symptoms: examination of baseline data from the REDUCE trial. European Urology 54 1379-1384. (doi:10.1016/j.eururo.2007.11.026)

Norata GD, Tibolla G, Seccomandi PM, Poletti A \& Catapano AL 2006 Dihydrotestosterone decreases tumor necrosis factor-alpha and lipopolysaccharide-induced inflammatory response in human endothelial cells. Journal of Clinical Endocrinology and Metabolism 91 546-554. (doi:10.1210/jc.2005-1664)

Penna G, Mondaini N, Amuchastegui S, Degli Innocenti S, Carini M, Giubilei G, Fibbi B, Colli E, Maggi M \& Adorini L 2007 Seminal plasma cytokines and chemokines in prostate inflammation: interleukin 8 as a predictive biomarker in chronic prostatitis/chronic pelvic pain syndrome and benign prostatic hyperplasia. European Urology 51 524-533. (doi:10.1016/j.eururo.2006.07.016)

Penna G, Fibbi B, Amuchastegui S, Corsiero E, Laverny G, Silvestrini E, Chavalmane A, Morelli A, Sarchielli E, Vannelli GB et al. 2009 The vitamin D receptor agonist elocalcitol inhibits IL-8-dependent benign prostatic hyperplasia stromal cell proliferation and inflammatory response by targeting the RhoA/Rho kinase and NF-kappaB pathways. Prostate 69 480-493. (doi:10.1002/pros.20896)

Piccinni MP, Giudizi MG, Biagiotti R, Beloni L, Giannarini L, Sampognaro S, Parronchi P, Manetti R, Annunziato F, Livi C et al. 1995 Progesterone favors the development of human $\mathrm{T}$ helper cells producing Th2-type cytokines and promotes both IL-4 production and membrane CD30 expression in established Th1 cell clones. Journal of Immunology 155 128-133.

Quintar AA, Roth FD, De Paul AL, Aoki A \& Maldonado CA 2006 Toll-like receptor 4 in rat prostate: odulation by testosterone and acute bacterial infection in epithelial and stromal cells. Biology of Reproduction 75 664-672. (doi:10.1095/biolreprod.106.053967)

Robinette CL 1988 Sex-hormone-induced inflammation and fibromuscular proliferation in the rat lateral prostate. Prostate 12 271-286. (doi:10.1002/ pros.2990120310)

Roehrborn CG, Nuckolls JG, Wei JT \& Steers W 2007 BPH Registry and Patient Survey Steering Committee. The benign prostatic hyperplasia registry and patient survey: study design, methods and patient baseline characteristics. BJU International 100 813-819.

Ropiquet F, Giri D, Lamb DJ \& Ittmann M 1999 FGF7 and FGF2 are increased in benign prostatic hyperplasia and are associated with increased proliferation. Journal of Urology 162 595-599. (doi:10.1016/S0022-5347(05)68632-6)

Rotondi M, Chiovato L, Romagnani S, Serio M \& Romagnani P 2007 Role of chemokines in endocrine autoimmune diseases. Endocrine Reviews $\mathbf{2 8}$ 492-520. (doi:10.1210/er.2006-0044)

Schauer IG \& Rowley DR 2011 The functional role of reactive stroma in benign prostatic hyperplasia. Differentiation 82 200-210. (doi:10.1016/j.diff. 2011.05.007)

Shigehara K, Sugimoto K, Konaka H, Iijima M, Fukushima M, Maeda Y, Mizokami A, Koh E, Origasa H, Iwamoto T et al. 2011 Androgen replacement therapy contributes to improving lower urinary tract symptoms in patients with hypogonadism and benign prostate hypertrophy: a randomised controlled study. Aging Male 14 53-58. (doi:10.3109/ 13685538.2010.518178)

Steiner GE, Stix U, Handisurya A, Willheim M, Haitel A, Reithmayr F, Paikl D, Ecker RC, Hrachowitz K, Kramer G et al. 2003a Cytokine expression pattern in benign prostatic hyperplasia infiltrating $\mathrm{T}$ cells and impact of lymphocytic infiltration on cytokine mRNA profile in prostatic tissue. Laboratory Investigation 83 1131-1146. (doi:10.1097/01.LAB. 0000081388.40145.65)

Steiner GE, Newman ME, Paikl D, Stix U, Memaran-Dagda N, Lee C \& Marberger MJ $2003 b$ Expression and function of proinflammatory interleukin IL-17 and IL-17 receptor in normal, benign hyperplastic, and malignant prostate. Prostate 56 171-182. (doi:10.1002/pros.10238)

Vignozzi L, Morelli A, Filippi S, Comeglio P, Chavalmane AK, Marchetta M, Toce M, Yehiely-Cohen R, Vannelli GB, Adorini L et al. 2011 Farnesoid X receptor activation improves erectile function in animal models of metabolic syndrome and diabetes. Journal of Sexual Medicine 8 57-77. (doi:10.1111/j.1743-6109.2010.02073.x)

Vignozzi L, Morelli A, Sarchielli E, Comeglio P, Filippi S, Cellai I, Maneschi E, Serni S, Gacci M, Carini M et al. 2012 Testosterone protects from metabolic syndrome-associated prostate inflammation: an experimental study in rabbit. Journal of Endocrinology 212 71-84. (doi:10.1530/JOE-11-0289)

Welsh M, Moffat L, McNeilly A, Brownstein D, Saunders PT, Sharpe RM \& Smith LB 2011 Smooth muscle cell-specific knockout of androgen receptor: a new model for prostatic disease. Endocrinology 152 3541-3451. (doi:10.1210/en.2011-0282)

Zhang XH, Morelli A, Luconi M, Vignozzi L, Filippi S, Marini M, Vannelli GB, Mancina R, Forti G \& Maggi M 2005 Testosterone regulates PDE5 expression and in vivo responsiveness to tadalafil in rat corpus cavernosum. European Urology 47 409-416. (doi:10.1016/j.eururo.2004.10.021)

Received in final form 3 May 2012

Accepted 4 May 2012

Made available online as an Accepted Preprint 4 May 2012 